\title{
Breast Cancer Risk - Genes, Environment and Clinics
}

\author{
Mammakarzinomrisiko - Gene, Umwelt und Klinik
}

Authors

Affiliations
P. A. Fasching ${ }^{1}$, A. B. Ekici² ${ }^{2}$ B. R. Adamietz ${ }^{4}$, D. L. Wachter ${ }^{3}$, A. Hein ${ }^{1}$, C. M. Bayer ${ }^{1}$, L. Häberle ${ }^{1}$, C. R. Loehberg ${ }^{1}$, S. M. Jud ${ }^{1}$, K. Heusinger ${ }^{1}$, M. Rübner ${ }^{1}$, C. Rauh ${ }^{1}$, M. R. Bani ${ }^{1}$, M. P. Lux ${ }^{1}$, R. Schulz-Wendtland ${ }^{4}$, A. Hartmann ${ }^{3}$, M. W. Beckmann ${ }^{1}$

The affiliations are listed at the end of the article

Schlüsselwörter
BRCA
O Mamma
O Mammakarzinom
O mammografische Dichte
O Plazenta
- Polymorphismus
Key words
O BRCA (breast cancer antigen)
breast
- breast feeding
- CAM (Complementary and
Alternative medicine)
cancer registry
O estrogen receptor

received $\quad 2.11 .2011$ revised 21.11.2011 accepted 21.11.2011

Bibliography

DOI http://dx.doi.org/ $10.1055 / \mathrm{s}-0031-1280437$ Geburtsh Frauenheilk 2011; 71: 1056-1066 @ Georg Thieme Verlag KG Stuttgart · New York · ISSN 0016-5751

Correspondence
Peter A. Fasching
Universitäts-Brustzentrum
Franken
Frauenklinik des Universitäts-
klinikums Erlangen
Friedrich-Alexander Universität
Erlangen-Nürnberg
Comprehensive Cancer Center
Erlangen-Nürnberg
Universitätsstraße 21-23
91054 Erlangen
peter.fasching@uk-erlangen.de

\section{Abstract}

$\nabla$

The information available about breast cancer risk factors has increased dramatically during the last 10 years. In particular, studies of low-penetrance genes and mammographic density have improved our understanding of breast cancer risk. In addition, initial steps have been taken in investigating interactions between genes and environmental factors. This review concerns with actual data on this topic. Several genome-wide association studies (GWASs) with a case-control design, as well as large-scale validation studies, have identified and validated more than a dozen single nucleotide polymorphisms (SNPs) associated with breast cancer risk. They are located not only in or close to genes known to be involved in cancer pathogenesis, but also in genes not previously associated with breast cancer pathogenesis, or may even not be related to any genes. SNPs have also been identified that alter the lifetime risk in $B R C A$ mutation carriers. With regard to nongenetic risk factors, studies of postmenopausal hormone replacement therapy (HRT) have revealed important information on how to weigh up the risks and benefits of HRT. Mammographic density (MD) has become an accepted and important breast cancer risk factor. Lifestyle and nutritional considerations have become an integral part of most studies of breast cancer risk, and some improvements have been made in this field as well. More than 10 years after the publication of the first breast cancer prevention studies with tamoxifen, other substances such as raloxifene and aromatase inhibitors have been investigated and have also been shown to have preventive potential. Finally, mammographic screening systems have been implemented in most Western countries during the last decade. These may be developed further by including more individualized methods of predicting the patient's breast cancer risk.

\section{Zusammenfassung \\ $\nabla$}

Das Wissen über Brustkrebsrisikofaktoren hat in den letzten 10 Jahren deutlich zugenommen. Insbesondere die Bedeutung von niedrigpenetranten Risikogenen konnte besser verstanden werden. Zusätzlich werden erste Schritte unternommen, um das Zusammenspiel zwischen Umweltfaktoren und genetischen Faktoren besser zu verstehen. Einige genomweite Assoziationsstudien von Fall-Kontroll-Studien und groß angelegte Validierungsstudien konnten mehr als ein Dutzend validierte Single Nucleotid Polymorphismen (SNPs) als genetische Risikofaktoren etablieren. Dabei handelt es sich um Veränderungen in Genen, von denen teilweise bekannt war, dass sie bei der Pathogenese des Mammakarzinoms eine Rolle spielen. Andere dieser Gene waren bislang noch nicht mit der Biologie des Mammakarzinoms in Verbindung gebracht worden. Auch konnten SNPs identifiziert werden, die das Lebenszeitrisiko von BRCA-Mutationsträgern modifizieren können. In Bezug auf nicht genetische Risikofaktoren hat das Wissen um die Hormonersatztherapie (HRT) in den letzten 10 Jahren deutlich zugenommen, sodass eine bessere Nutzen-Risiko-Bewertung vorgenommen werden konnte. Die mammografische Dichte hat sich als wichtiger und akzeptierter Risikofaktor etabliert. Lifestyle und Ernährung werden nach wie vor mit großem Interesse als Risikofaktoren für das Mammakarzinom untersucht. Einige Studien konnten auch auf diesem Gebiet das Wissen erweitern. Mehr als 10 Jahre nach der Publikation der ersten Chemopräventionsstudien gibt es nunmehr nicht nur zur Substanz Tamoxifen Ergebnisse. Auch zu Raloxifen und Aromatasehemmern gibt es Studien, die deren protektive Wirkung nachgewiesen haben. Schließlich wurde in den meisten westlichen Industrieländern das Mammografiescreening als Früherkennung etabliert und bereits jetzt werden Überlegungen unter- 
nommen, wie man durch die Integration von individualiserter Risikoprädiktion die Früherkennung verbessern könnte.

\section{Introduction}

Breast cancer risk is an estimate of the probability of whether a woman will or will not develop breast cancer over a defined period of time. Although this definition is rather abstract, breast cancer risk is increasingly being used in the field of breast cancer prevention and detection to improve health care for both healthy and diseased women.

There have been several attempts to classify risk factors, but the rough distinction between genetic and nongenetic risk factors has been proved to be one of the most stable ones. Nongenetic risk factors refer to any circumstance that is not inherited, such as nutrition, environmental toxins, or the use of hormone replacement therapy (HRT). Genetic risk factors refer to genetic changes in the somatic DNA inherited at the time of birth or conception. However, it may be difficult to categorize some risk factors into one of these two classes. Mammographic density (MD), for example, is known to be a very powerful risk factor, but there is evidence both that it is inherited and that it results from environmental changes. Similarly, epigenetic changes in DNA may be influenced by environmental factors, but represent physical and chemical changes in the DNA.

Whereas risk factor research is mainly concerned with epidemiological effects, research into carcinogenesis in the breast is concerned with the molecular mechanisms through which a healthy breast cell turns into a cancer cell. Information about these pathways could be helpful for developing new targeted prevention strategies and drugs against breast cancer. The concept of targeted therapy has been pursued for more than a decade in breast cancer treatment. Some tumor types, such as HER2-positive, hormone receptor-positive, and basal-like breast cancers, are considered to be biologically different and to require different types of treatment [1-4]. Similarly, the ability to predict a specific subtype of breast cancer using risk factors could be helpful in establishing targeted and individualized methods of breast cancer prevention.

\section{How to Obtain Information About Breast Cancer Risk $\nabla$}

Understanding the etiology of a disease is necessary for physicians to fulfill their role in the primary prevention of the disease. It is necessary to know about causative agents or circumstances in order to be able to eliminate patients' exposure to causative risk factors. Information about risk factors is mostly obtained either from case-control studies or from cohort studies, in which patients with the disease and patients without the disease are compared with each other. During the last two decades, as genetic variations have been increasingly analyzed as risk factors, studies with a case-only design have also been used to investigate interactions between genetic risk factors and environmental risk factors, as well as other subgroups in the case population.

Cohort studies are longitudinal studies in which the investigator observes a group of participants who either are or are not exposed to the risk factor being investigated. The risk of whether an individual will develop the disease in the exposed cohort in relation to the risk for an individual in the unexposed cohort is called relative risk (RR).
A case-control study takes advantage of the easy accessibility of patients who already have disease (prevalent cases) and compares the frequency of specific characteristics (allele distribution, hormone replacement therapy use) in the two groups of cases and controls. The ratio between the odds of the event (e.g., breast cancer) occurring in one group and the odds of it occurring in the other group is known as the odds ratio (OR). If the disease occurs rarely, then the $\mathrm{OR}$ is a good approximation to the RR.

\section{Genetic Risk Factors \\ $\nabla$}

In addition to epidemiological factors, a family history of breast or ovarian cancer is another major risk factor that can contribute to the evaluation of a woman's lifetime risk. Population-based case-control studies have reported an approximately threefold increase in risk in first-degree relatives of breast cancer patients. In principle, the familial aggregation of breast cancer may be the result of genetic or nongenetic factors that are shared within families; however, since the discovery of breast cancer genes 1 and 2 (BRCA1 and BRCA2) in 1994 and 1995 [5, 6], as well as other high-penetrance susceptibility genes such as CHEK2, it is clear that the risk of breast cancer has a substantial genetic component.

Approximately $3-8 \%$ of invasive breast cancers are attributable to inherited mutations in high-penetrance genes, including BRCA1 and BRCA2, but also genes such as CHEK2 and TP53. Most deleterious $B R C A$ mutations encode truncated protein products, although missense mutations that alter a single amino acid in $B R C A 1$ or BRCA2 have been found to segregate with disease in some familial breast and ovarian cancer clusters [7,8]. Inheritance of a BRCA mutation increases the lifetime risk of ovarian cancer from a baseline level of $10 \%$ to about $40 \%$ in BRCA2 carriers and $60 \%$ in BRCA1 carriers [9]. Highly penetrant germline $B R C A$ mutations are rare, however, and are carried by less than one in 500 individuals in most populations. There are some notable exceptions, particularly the Ashkenazi Jewish population, in which the carrier frequency is estimated to be one in 40 [10]. Although functional explanations, testing opportunities, and preventive options for BRCA mutation carriers are clear, BRCA mutations are rare, and the overall impact on mortality will inevitably be small.

More recently, it has been shown that there are common, weakly penetrant alleles that contribute to the burden of cancers that are often classified as sporadic (i.e., without a heritable basis). In addition, genetic variations have been discovered and validated that modify the risk in BRCA mutation carriers. Several million common genetic variants (polymorphisms) have been identified in the human genome [11-15]. The most common of these polymorphisms involve substitution of a single nucleotide (SNP). Many SNPs are either located outside of genes or within introns. When they are located within coding sequences, they are frequently "silent" substitutions, which are not predicted to have a functional effect (i.e., they do not change the amino acid sequence). However, some SNPs do change the amino acid code (they are nonsynonymous) and may significantly alter the activity of a protein or its interactions with other molecules. SNPs that arise within introns or promoter regions may also conceivably al- 
ter the expression of the protein by affecting transcription. Most genes contain numerous polymorphisms, and current estimates suggest that there is on average one common SNP in every 250 base pairs across the genome. The most common approach to identifying common polymorphisms that predispose more weakly to cancer than high-penetrance genes is the genetic association study, in which the frequencies of SNPs are compared between large population-based series of cases with age-matched and population-matched unaffected controls $[11,16]$. Although the disease risks caused by these polymorphisms are less prominent than with genes such as BRCA1 and BRCA2, they can account for a larger proportion of disease by virtue of their much higher prevalence in the population.

Two approaches can be taken in performing genetic association studies - direct and indirect. In the direct approach, putative functional variants, usually on selected candidate genes, are studied in the expectation that they are causally related to the disease of interest. Alternatively, the indirect approach takes advantage of the fact that polymorphisms in close physical proximity are often inherited together as a haplotype block. By elucidating the haplotype structure surrounding genes of interest, the number of SNPs that need to be examined in order to obtain most of the genetic information at a locus is reduced, because any one SNP tags the genetic information of all the other tightly correlated SNPs (http://www.hapmap.org/) [13].

An extension of this tagging approach uses array-based technologies that enable rapid analysis of millions of tagged SNPs throughout the genome in case-control association studies, commonly referred to as a genome-wide association study (GWAS). GWASs are defined by the National Institutes of Health in the United States as studies of common genetic variations across the entire human genome, designed to identify genetic associations with observable traits [17].

An enormous variety of publications have appeared on SNPs in candidate genes. Most of the associations described have not been reproduced. An example of a more systematic approach was undertaken by a large consortium that followed the clear strategy of identifying SNPs in genome-wide association studies and validating the findings in multiple case-control studies from several continents, with almost 60000 breast cancer cases and 60000 controls and available genotypes. Eleven SNPs have so far been validated as risk factors for sporadic breast cancer ( Table 1). In a multistage GWAS, five of these 11 SNPs were identified and confirmed in an initial validation effort at the $\mathrm{p}<10^{-8}$ level. These SNPs include the intronic rs2981582 in the FGFR2 gene (per-allele OR 1.26; 95\% CI, 1.23 to 1.28 ); rs3803662, a synonymous coding SNP of LOC643714 that lies $8 \mathrm{~kb}$ upstream of TNRC9=TOX3 (per-allele OR 1.20; 95\% CI, 1.16-1.24); rs889312, which is related to a linkage disequilibrium block containing the MAP3K1 gene (per-allele OR 1.13; 95\% CI, 1.10-1.16); rs3817198, which is in intron 10 of LSP1 (per-allele OR 1.07; 95\% CI, 1.041.11); and rs13281615 on 8q24 (per-allele OR 1.08; $95 \% \mathrm{CI}$, 1.05-1.11) [18]. In a second validation effort in this GWAS, two further SNPs were validated. The first was rs4973768, which is located on chromosome $3 \mathrm{p}$ near the potential causative genes SLC4A7 and NEK10 and was shown to be associated with an increased breast cancer risk per allele of 1.11 (95\% CI, 1.08-1.13; $\mathrm{p}<10^{-22}$ ) [19]. The second was rs6504950, which was associated with a decreased breast cancer risk (OR 0.95; 95\% CI, 0.92-0.97, $\mathrm{p}<10^{-7}$ ). The latter SNP is reported to be associated with a higher expression level of COX11 in lymphocytes, but lies within intron 1 of STXBP4 [19]. Similarly, rs13387042, initially identified in a
Table 1 Validated risk factor single nucleotide polymorphisms (SNPs) for sporadic breast cancer.

\begin{tabular}{|c|c|c|c|c|}
\hline SNP & Gene symbol & MAF & $\mathrm{OR}^{*}$ & $\begin{array}{l}\text { Refer- } \\
\text { ence }\end{array}$ \\
\hline rs17468277 & $\begin{array}{l}\text { (merged with rs1045485 } \\
\text { G>C) CASP8/ALS2CR12; } \\
\text { 2q33-q34 }\end{array}$ & 0.13 & 0.88 & {$[24]$} \\
\hline rs1982073 & TGFB1 L10P & 0,45 & 1.08 & [23] \\
\hline rs2981582 & $\begin{array}{l}\text { FGFR2/LOC100131885; } \\
\text { 10q26 }\end{array}$ & 0.38 & 1.26 & [18] \\
\hline rs13281615 & $\begin{array}{l}\text { Intergenic, FAM84B/c-MYC; } \\
8 \mathrm{q} 24\end{array}$ & 0.40 & 1.08 & [18] \\
\hline rs3817198 & LSP1/H19; 11p15 & 0.30 & 1.07 & [18] \\
\hline rs889312 & $\begin{array}{l}\text { MAP3K1/MGC33648/ } \\
\text { MIER3; 5q11 }\end{array}$ & 0.28 & 1.13 & [18] \\
\hline rs3803662 & $\begin{array}{l}\text { TNRC9/TOX3/LOC643714; } \\
\text { 16q12 }\end{array}$ & 0.25 & 1.20 & [18] \\
\hline rs13387042 & $\begin{array}{l}\text { Intergenic 2q35/TNP1/ } \\
\text { IGFBP5/IGFBP2/TNS1 }\end{array}$ & 0.52 & 1.12 & [21] \\
\hline rs4973768 & SLC4A7/NEK10; 3p24 & 0.46 & 1.11 & [19] \\
\hline rs6504950 & $\begin{array}{l}\text { STXBP4/COX11/TOM1L1; } \\
17 q 23\end{array}$ & 0.27 & 0.95 & [19] \\
\hline rs10941679 & $5 p 12$ & 0.26 & 1.19 & {$[20]$} \\
\hline
\end{tabular}

MAF: major allele frequency; OR: odds ratio; * all p values $<10^{-5}$.

GWAS based in Iceland [20], was found to be associated with an increased breast cancer risk, with a per-allele OR of 1.12 (95\% CI, 1.09-1.15; $\mathrm{p}<10^{-18}$ ) [21]. rs13387042 lies in a 90-kb region of high linkage disequilibrium that contains neither known genes nor noncoding RNA. The Breast Cancer Association Consortium (BCAC) also validated rs10941679, which was first described in another Icelandic study $[20,22]$. This SNP is located in the 5p1211 region, which contains the genes FGF10 and MRPS30; FGF10 is involved in growth factor signal transduction and MRPS30 in apoptosis signaling. The $\mathrm{G}$ allele of rs10941679 is associated with an increased breast cancer risk (OR 1.19, p < 10-10) [20].

Two SNPs have been validated from candidate gene approaches [23]. The first of these was rs1982073, a missense polymorphism in the TGFB1 gene, which in a joint analysis of BCAC studies revealed an association with breast cancer risk (per-allele OR 1.08; 95\% CI, 1.04-1.11, p < 10-4) [24]. Similarly, a nonsynonymous change in the CASP8 gene, rs1045485, was found to decrease breast cancer risk, with a per-allele OR of 0.88 (95\% CI, $0.84-$ $\left.0.92, \mathrm{p}<10^{-6}\right)[24]$.

\section{SNPs and Disease Risk Modification in BCRA Mutation Carriers \\ $\nabla$}

A GWAS in BRCA1 mutation carriers revealed two SNPs close to the gene ANKLE1/MERIT40 on chromosome 19p13 as being risk modifiers. The same SNPs have been shown to be risk factors specifically for triple-negative sporadic breast cancer as well. rs8170 showed an OR of 1.28 per allele (95\% CI, 1.16-1.41) and rs2363956 an OR of 0.80 (95\% CI, 0.74-0.87) per allele.

In addition to genetic variants, there is further evidence that the SNPs that have been identified in sporadic breast cancer studies also modify the risk in BRCA1 and BCRA2 mutation carriers ( Table 2). Interestingly, most of the SNPs have an effect only in BRCA2 mutation carriers. 
Table 2 Single nucleotide polymorphisms (SNPs) as modifiers of lifetime risk in BRCA mutation carriers.

\begin{tabular}{|c|c|c|c|c|c|c|}
\hline \multirow[b]{2}{*}{ SNP } & \multirow[b]{2}{*}{ Gene/region } & \multicolumn{2}{|c|}{ BRCA1 mutation carriers } & \multicolumn{3}{|c|}{ BRCA2 mutation carriers } \\
\hline & & HR $(95 \% \mathrm{Cl})$ & $\mathrm{p}$ value & HR ( $95 \%$ Cl) & $\mathrm{p}$ value & Reference \\
\hline rs1801320 & RAD51 & $1.59(0.96-2.63)$ & 0.07 & $3.18(1.39-7.27)$ & $<0.001$ & [113] \\
\hline rs 1045485 & CASP8 & $0.85(0.76-0.97)$ & 0.01 & $1.06(0.88-1.27)$ & 0.60 & [114] \\
\hline rs2981522 & FGFR2 & $1.02(0.95-1.09)$ & 0.60 & $1.32(0.20-1.45)$ & $<10^{-7}$ & [115] \\
\hline rs3803662 & TOX3 & $1.11(1.03-1.19)$ & $<0.01$ & $1.15(1.03-1.27)$ & $<0.01$ & [115] \\
\hline rs889312 & МАРКЗКК1 & $0.99(0.93-1.06)$ & 0.90 & $1.12(1.02-1.24)$ & 0.02 & [115] \\
\hline rs3817198 & LSP1 & $1.05(0.99-1.11)$ & 0.90 & $1.16(1.07-1.25)$ & $<0.001$ & [116] \\
\hline rs13387042 & $2 q 35$ & $1.14(1.04-1.25)$ & $<0.01$ & $1.18(1.04-1.33)$ & $<0.01$ & [116] \\
\hline rs13281615 & $8 q 24$ & $1.00(0.94-1.05)$ & 0.90 & $1.06(0.98-1.14)$ & 0.20 & [116] \\
\hline rs 8170 & MERIT4O & $1.26(1.17-1.35)$ & $<10^{-8}$ & $0.90(0.77-1.05)$ & 0.20 & [90] \\
\hline rs2363956 & MERIT40 & $0.84(0.80-0.89)$ & $<10^{-8}$ & $1.12(0.99-1.27)$ & 0.07 & [90] \\
\hline rs 2046210 & $6 q 25.1$ & $1.17(1.11-1.23)$ & $<10^{-8}$ & $1.06(0.99-1.14)$ & 0.09 & [117] \\
\hline rs9397435 & $6 q 25.1$ & $1.28(1.18-1.40)$ & $<10^{-7}$ & $1.14(1.01-1.28)$ & 0.03 & [117] \\
\hline rs11249433 & $1 \mathrm{p} 11.2$ & $0.97(0.92-1.02)$ & 0.2 & $1.09(1.02-1.17)$ & 0.015 & [117] \\
\hline
\end{tabular}

Cl: confidence intervals; HR: hazard ratio; SNP: single nucleotide polymorphism.

Table 3 Examples of established nongenetic risk factors.

\begin{tabular}{|c|c|c|c|c|}
\hline Factor & Comparator & $\mathrm{OR}^{*} / \mathrm{HR}^{* *} / \mathrm{RR}^{* * *}(95 \% \mathrm{Cl})$ & Remark & Reference \\
\hline Estrogen + progestin HRT & no HRT & $1.25^{* *}(1.07-1.46)$ & & [33] \\
\hline Birth & one child less & $0.93 *(0.91-0.97$ & risk reduction per child & [25] \\
\hline 12 months' breastfeeding & 12 months less breastfeeding & $0.96 *(0.94-0.97)$ & $\begin{array}{l}\text { risk reduction per } 12 \text { months' } \\
\text { breastfeeding }\end{array}$ & [25] \\
\hline $\begin{array}{l}\text { First-degree relative } \\
\text { with breast cancer }\end{array}$ & $\begin{array}{l}\text { no first-degree relative } \\
\text { with breast cancer }\end{array}$ & $\begin{array}{l}1.78^{* * *}-2.61^{* * *} \\
\text { (Cl not reported) }\end{array}$ & $\begin{array}{l}\text { figures from the BCDDP and } \\
\text { the Nurses' Health Study }\end{array}$ & [118] \\
\hline History of breast biopsy & no history of breast biopsy & $1.9^{* * *}(1.2-2.9)$ & & [119] \\
\hline $\begin{array}{l}\text { History of atypical } \\
\text { breast biopsy }\end{array}$ & $\begin{array}{l}\text { no history of atypical } \\
\text { breast biopsy }\end{array}$ & $5.3 * * *(3.1-8.8)$ & & [119] \\
\hline Age at menarche $>14$ & age at menarche $<12$ & ${ }^{*} 0.77$ (Cl not reported) & & [120-122] \\
\hline Age at menopause $<45$ & age at menopause $>54$ & $2.0^{*}(\mathrm{Cl}$ not reported $)$ & & [120-122] \\
\hline
\end{tabular}

$\mathrm{Cl}$ : confidence intervals; HR: hazard ratio; HRT: hormone replacement therapy; OR: odds ratio; RR: relative risk.

\section{Nongenetic Risk Factors}

\section{$\nabla$}

It has long been known that environmental factors such as radiation and toxins can have an influence on cancer risk. Some associations, such as radiation, appear to be directly linked to a hypothesized mechanism of action (i.e., direct DNA damage), while some are more complex - such as nutrition, sports, and obesity. Others might be a reflection of both inherited factors and environmental factors, such as mammographic density. @ Table 3 gives an overview of common non-genetic risk factors.

\section{Pregnancies and breastfeeding}

Pregnancies and breastfeeding are thought to have two effects on a woman's breast cancer risk. During and shortly after pregnancy, women have an increased risk of breast cancer, but later in life the breast cancer risk is lower in comparison with women who have never given birth to a child. Most studies use a design that examines women at a later stage of their life cycle and provides data on the risk-reducing effect. Women with no live deliveries have a lifetime risk of about $6.3 \%$ up to the age of 70 [25]. The risk decreases with each pregnancy. The relative risk of breast cancer decreases by $4.3 \%$ (95\% CI, 2.9-5.8) for every 12 months of breastfeeding, in addition to a decrease of 7.0\% (95\% CI, 5.0-9.0) for each birth [25].
During the pregnancy and for several years afterwards, the breast cancer risk appears to be transiently increased. This effect is greater the later in life the first full-term pregnancy was completed. For women who were aged 35 at the time of their first delivery, the risk 5 years later is reported to be 1.26 (95\% CI, 1.101.44). However, 15 years after delivery, the risk decreases to below the risk level in nulliparous women [26].

\section{Hormone replacement therapy}

Initial reports from the Women's Health Initiative (WHI) study were published in 2002, after the study had to be terminated early. The study compared women with and without hormone replacement therapy, with a prospective and randomized design. The study revealed trends that HRT increased the rate of cardiovascular disease [27] and breast cancer [28]. At the same time, the Million Women Study, a cohort study in the United Kingdom, published similar results [29]. Since then, prescription and usage behavior in relation to HRT have changed drastically [30], and this may have led to a decrease in the incidence of hormone receptor-positive breast cancer [31,32]. One of the most recent updates of the WHI data, comparing the placebo arm with the combined estrogen plus progestin arm, not only reported that the breast cancer risk is increased with a hazard ratio (HR) of 1.25 (95\% CI, 1.07-1.46), but also that the breast cancer-specific mor- 

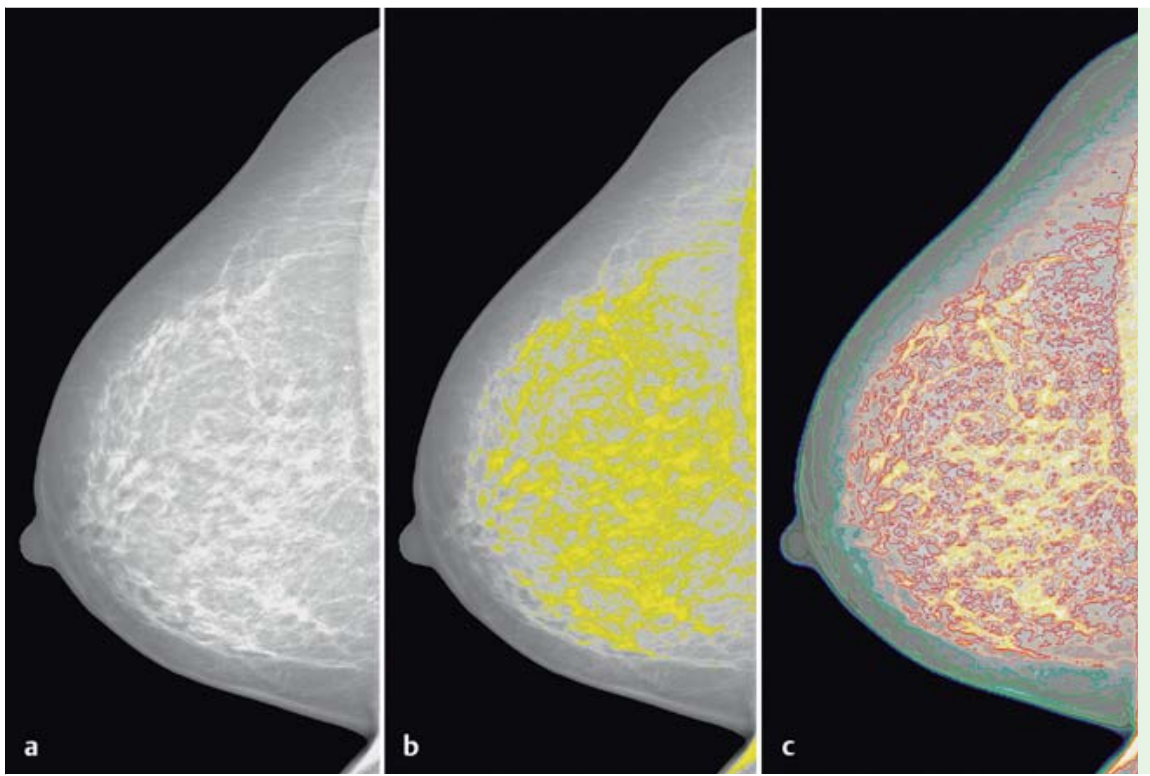

Fig. 1 a to c Computer-assisted assessment of mammographic density of a digitized mammogram (a) using the Madena computer program. The yellow marks represent a threshold, which is arbitrarily set by a user of the software (b), and the colored marks represent a priory defined gray level intervals (c) [46].

tality in the HRT arm was higher, with an HR of 1.96 (95\% CI, 1.00-4.04) [33].

However, HRT is still one of the most effective treatments for menopausal symptoms. Other forms of treatment are under investigation, such as the synthetic steroid hormone tibolone, which was initially thought to have a selective binding profile with few effects on the female breast. It has been shown, however, that tibolone increases the frequency of recurrences after breast cancer [34-36], and caution is therefore warranted with this drug as well.

\section{Mammographic density}

Mammographic density (MD) is one of the most important risk factors for breast cancer. Women with a high MD have an up to fivefold increase in the risk for breast cancer [37-39].

Radiological assessment of breast density has been extensively investigated during the last 30 years. Subjective methods include Wolfe's patterns, using four categories $[40,41]$; Boyd's classification, with six categories [42]; and subjective assessment of the percentage density by a reader, with values between 0 and $100 \%$ [43]. Due to the substantial variations observed with completely subjective methods and obvious misclassifications, several com- puter-assisted methods have also been developed, such as Madena and Cumulus [44-46]. Mammographically dense areas can be marked using a gray level value threshold, and the percentage of this area in relation to the total breast area can be calculated (- Fig. 1).

Most studies have been concerned with postmenopausal women and have reported an increased breast cancer risk, with ORs between 2.7 and 6.0. In studies comparing percentage densities of $>50 \%$ with values under $10 \%$, the OR was about 3 , and in studies comparing densities over $75 \%$ with those under $5 \%$, the ORs were about 4.5 ( Table 4 ).

There is continuing debate as to why MD increases the risk of breast cancer. It is commonly accepted that although mammographic density is strongly associated with other very strong risk factors for breast cancer, such as age, parity, and body mass index [47-49], it remains an independent risk factor that improves the risk prediction for breast cancer in addition to the other correlated risk factors.

Biologically, percentage mammographic density has been associated with the amount of collagen and cell quantity in the breast. It is thought that proliferation is higher in mammographically dense breasts and that mammographic density mirrors the effect

Table 4 Risk estimates for mammographic density in studies using percentage mammographic density as a measure.

\begin{tabular}{|c|c|c|c|c|c|c|c|}
\hline Country & Year & Age & Cases (n) & Controls (n) & Comparison & OR (95\% Cl) & Reference \\
\hline USA & 1991 & $35-74$ & 266 & 301 & $<5 \%$ vs. $\geq 65 \%$ & $4.3(2.1-8.8)$ & [123] \\
\hline USA & 1995 & $35-75$ & 1880 & 2152 & $0 \%$ vs. $\geq 75 \%$ & $4.3(3.1-6.1)$ & {$[124]$} \\
\hline Canada & 1995 & $40-59$ & 330 & 330 & $0 \%$ vs. $\geq 75 \%$ & $6.0(2.8-13.0)$ & {$[42]$} \\
\hline Netherlands & 2000 & $>45$ & 129 & 517 & $<5 \%$ vs. $>25 \%$ & $2.9(1.6-5.6)$ & [125] \\
\hline USA & 2002 & $<50$ & 547 & 472 & upper vs. lower quartile & $4.4(3.0-6.7)$ & [126] \\
\hline UK & 2005 & $40-80$ & 111 & 3100 & $0.5 \%$ vs. $>46 \%$ & $3.5(1.4-5.2)$ & [127] \\
\hline Japan & 2005 & premenopausal & 71 & 370 & $0 \%$ vs. $75-100 \%$ & $4.37(1.24-15.4)$ & [128] \\
\hline Japan & 2005 & postmenopausal & 75 & 389 & $0 \%$ vs. $75-100 \%$ & $4.19(1.33-13.2)$ & [128] \\
\hline USA & 2006 & 60 & 607 & 667 & $<10 \%$ vs. $>50 \%$ & $3.6(2.3-5.6)$ & [129] \\
\hline Canada & 2007 & $40-70$ & 1114 & 1114 & $<10 \%$ vs. $\geq 75 \%$ & $4.7(3.0-7.4)$ & [39] \\
\hline Japan & 2008 & $50-93$ & 205 & 223 & highest vs. lowest quintile & $3.02(1.58-5.77)$ & [130] \\
\hline Germany & 2011 & $28-80$ & 1025 & 520 & $<10 \%$ vs. $\geq 50 \%$ & $2.7(1.3-5.4)$ & [38] \\
\hline Singapore & 2011 & $45-69$ & 491 & 982 & $<10 \%$ vs. $>75 \%$ & $5.54(2.38-12.9)$ & [131] \\
\hline
\end{tabular}

Cl: confidence intervals; OR: odds ratio. 
of mitogens and mutagens on the breast tissue. Metalloproteinases and other factors of the extracellular matrix also appear to play a role in the association between mammographic density and breast cancer risk (reviewed in [50]).

\section{Lifestyle, nutrition, and body weight}

It is a well-known fact that a healthy lifestyle and nutrition and a normal body weight are associated with a lower incidence of many diseases. Cancer is one of these. The World Cancer Research Fund International (WCRFI) and German Institute for Nutritional Research (Deutsches Institut für Ernährungsforschung, DIfE) have summed up the global aspects involved in a healthy lifestyle and cancer prevention [51].

Most studies concerned with breast cancer risk and nutrition or lifestyle mention body mass index (BMI) as a risk factor. Recently, physical exercise has been specifically investigated in relation to preventive effects on the development of breast cancer. The WCRFI reports that $60 \%$ of the female population in the United States are overweight, in comparison with only $28 \%$ of Japanese women. In Germany, the corresponding figures range from 42 to $56 \%$, depending on the geographic region. The German population is considered to have the highest prevalence of excess weight in Europe $[51,52]$. Not only has the postmenopausal breast cancer risk been consistently shown to be increased in women with an increased body weight, but also the risk for colon cancer, endometrial cancer, esophageal adenocarcinoma, and renal cell cancer. There is also evidence that the risk for pancreatic cancer, thyroid cancer, ovarian cancer, cervical cancer, prostate cancer, and some types of lymphoma may be increased by greater body weight as well [53-56].

Studies investigating physical exercise as a preventive measure against breast cancer are rare and mostly underpowered, but one study described a reduction in breast cancer risk in postmenopausal women who achieved a decrease in their BMI through physical exercise during the observation period [57].

With regard to dietary patterns and breast cancer risk, a metaanalysis of 16 studies showed that across all of the studies included, a prudent/healthy dietary pattern was able to decrease the risk of breast cancer. An increased breast cancer risk was seen in the group of women with an alcohol abuse pattern [58]. Research studies in this field are difficult to compare, as the definitions of dietary patterns differ from study to study.

Dietary components have been investigated in several studies, examining vitamins, trace elements, intake of vegetables and fruit, and nutrition supplements. However, systematic reviews have not been able to conclude that an increased intake of fruit and vegetables is associated with a reduced risk of breast cancer $[59,60]$. Similarly, no associations have been found for most antioxidant vitamins, such as vitamins A, C, and E. With vitamin D, however, there is growing evidence for a protective effect and for the possible molecular mechanism of action. In a meta-analysis including 4441 cases and 6754 controls with data available for serum 25-hydroxyvitamin D [25(OH)D], a clear protective effect was found. The RR for all studies was 0.73 (95\% CI, 0.60-0.88) for every $20 \mathrm{ng} / \mathrm{mL} 25(\mathrm{OH}) \mathrm{D}$ serum level. However, there was considerable variability amongst the studies, particularly in the nested case-control studies [61].

There have also been several reports on an inverse relationship between dietary calcium intake and breast cancer risk [62-66], although some studies have not observed this effect [67-69].

\section{Complementary and alternative substances}

such as soy and isoflavones

In view of the lower breast cancer incidence in Asian countries, it was debated for a considerable period whether soy intake might be at least partly responsible for the observation. Soy foods contain high doses of isoflavones, a class of phytoestrogens. Isoflavones are known to have a weak estrogenic effect, but it has been hypothesized that the effect is associated with an anticarcinogenic component. The largest meta-analysis on this issue included 18 studies, with 13188 cases and approximately 1.1 million controls from case-control and cohort studies comparing women with and without soy food exposure. The authors concluded that soy intake may be associated with a small reduction in breast cancer risk, but that due to the wide variation in the studies and an absence of a dose-dependent effect, the results have to be interpreted with caution and a high-dose isoflavone intake cannot be recommended on the basis of these findings [70]. A more recent, but smaller, meta-analysis concluded that only high-dose soy intake may be associated with a reduced risk of breast cancer, although this effect was only seen in Asian populations [71]. It may therefore be difficult to draw any conclusions for Caucasians, in view of different patterns of genetic and environmental risk factors.

\section{Gene-Environment Interactions \\ $\nabla$}

The establishment of large international consortia, with sample sizes that are sufficient to address the relevant questions without leading to an inflationary increase in false-positive reports, has recently made it possible to analyze interactions between genetic risk factors and environmental risk factors. It is clear that environmental risk factors do not have the same effect on each individual. This might be due either to the variety of factors involved and exposure to different environmental risk factors, or to the individual's genetic background.

The Breast Cancer Association Consortium (BCAC) analyzed classic reproductive risk factors and BMI in relation to their interaction with 12 published and validated breast cancer SNPs, and no interaction was identified [72]. Similarly, 12 SNPs (nine overlapping SNPs in the BCAC analysis) were analyzed with regard to interactions with age at menarche, parity, age at first birth, breastfeeding, menopausal status, age at menopause, HRT use, BMI, and alcohol intake in the One Million Women study. Again, no interaction was found [73]. The third, recent study, investigating 17 SNPs and the above-mentioned environmental factors, did not support the hypothesis that common genetic risk factors interact with established breast cancer risk factors [74].

These three studies represent the start of investigations on interactions between genetic and environmental risk factors in breast cancer. Future analyses may face the challenge of finding ways of measuring environmental exposure and selecting the correct genetic risk factors to be able to identify true associations [75].

\section{Breast Cancer Assessment in Practice \\ $\nabla$}

The information available about breast cancer risk has now become truly comprehensive. It has been applied in practice in the large breast cancer prevention trials, selecting for women with an increased risk for breast cancer, but the use of breast cancer risk assessment tools in clinical practice appears to be limited 


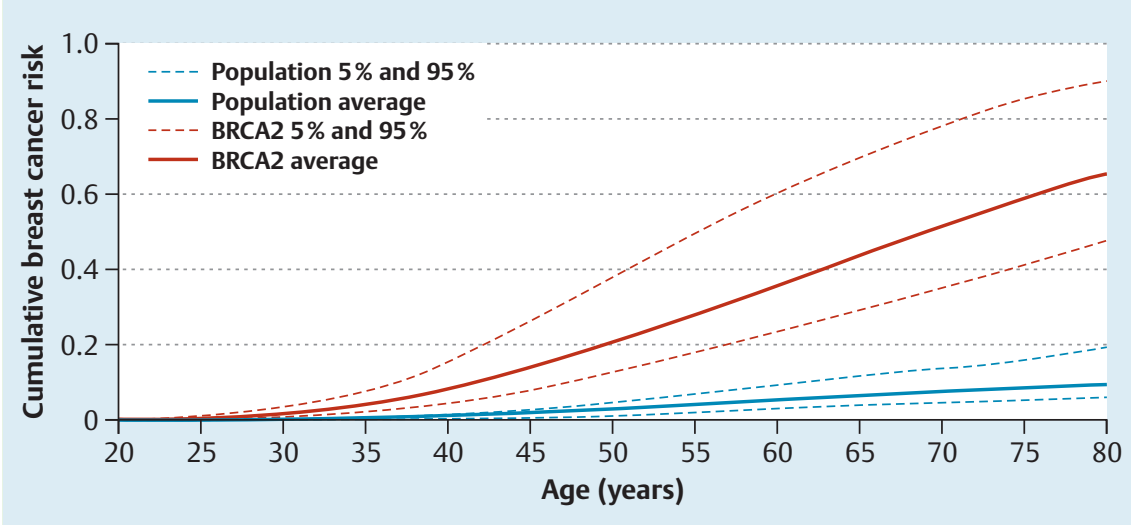

Fig. 2 Modification of lifetime breast cancer risk by 18 validated breast cancer single nucleotide polymorphisms (SNPs) in patients with (red) and without (blue) BRCA2 mutations (adapted from [87]). The figure shows the risks for an average individual and the risks for individuals at the 5 th and 95th percentiles of a combined SNP effect, assuming the same relative risks apply to the general population and to BRCA2 mutation carriers.

with regard to all aspects of prevention, intensified early detection, prophylactic medication, and prophylactic surgery.

Several tools have been developed for assessing breast cancer risk; some of the most frequently used are summarized in 0 Table 5 in relation to their use of risk factor information [76-85]. Some have been in use for decades already, such the Gail model [84], while others such as the Tice model, which includes mammographic density, have been developed only recently [86].

Adding genetic variants might be a way of improving the prediction models further. The lifetime risk up to the age of 80 is generally $9.2 \%$ in the general population and approximately $65 \%$ in BRCA2 mutation carriers. When 18 low-penetrance SNPs are included in a hypothetical risk model [87], the general population can be divided into women who have a lifetime risk of about $20 \%$ and those with a lifetime risk of about $6 \%$, at the extreme ends of the distribution. With regard to the influence on the lifetime risk in BRCA2 mutation carriers, the prediction model can distinguish between women with a lifetime risk of about $90 \%$ and those with a lifetime risk of about 48\% [87] ( Fig. 2). However, adding 10 validated breast cancer risk SNPs in 5590 breast cancer cases and 5998 controls to the Gail model only showed a weak improvement in comparison with risk prediction using the Gail model alone [88].
Models for breast cancer risk prediction do not at present distinguish between distinct molecular subtypes, although subtypespecific risk factors have already been identified [21,89-93]. However, predicting breast cancer and assessing specific risks can only make sense if they address women who have a high likelihood of developing a cancer with an unfavorable prognosis. As early detection and cancer treatment also have an impact on survival $[94,95]$, studies would ideally have to be designed in order to predict which women are likely to have an aggressive tumor that can be detected early.

\section{Early Detection and Risk Reduction}

It is known that surveillance of women who have a clearly increased risk of breast cancer can detect lesions at an earlier stage [96], offering greater chances of survival and less toxic treatment; specific recommendations for women with a clearly elevated lifetime risk have been published and put into practice [97]. With increasing awareness of the risk of breast cancer in women who are at moderate to low risk, however, the question arises of how to address this risk in clinical practice.

Table 5 Breast cancer risk assessment programs.

\begin{tabular}{|c|c|c|c|c|c|c|}
\hline Risk factor & $\mathrm{NCl}$ model & Claus model & BRCAPro & Tyrer et al. & BOADICEA & Tice et al. \\
\hline Reference & {$[83,84]$} & [85] & [76-78] & [81] & {$[79,80,82]$} & {$[86]$} \\
\hline Age & + & + & + & + & + & + \\
\hline Age at menarche & + & & & + & & \\
\hline Age at menopause & & & & + & & \\
\hline BMI & & & & + & & \\
\hline Age at first birth & + & & & + & & \\
\hline History of breast biopsies & + & & & + & & + \\
\hline History of premalignant lesions & + & & & + & & \\
\hline HRT & & & & + & & \\
\hline Family history of breast cancer & + & + & + & + & + & \\
\hline Family history of ovarian cancer & & & + & + & + & \\
\hline Family history of other cancers & & & & & + & \\
\hline Contralateral breast cancer & & & + & + & + & \\
\hline Male breast cancer & & & + & & & \\
\hline$B R C A$ mutation & & & $(+)$ & & + & \\
\hline Ethnicity & + & & & & & + \\
\hline Mammographic density & & & & & & + \\
\hline
\end{tabular}

BMI: body mass index; BOADICEA: Breast and Ovarian Analysis of Disease Incidence and Carrier Estimation Algorithm; HRT: hormone replacement therapy; NCI: National Cancer Institute. 
Mammography screening has been introduced in most industrialized countries and is carried out on a large scale and with high standards and quality controls [98]. The decision on whether to screen a population or part of it is based on weighing up the benefits against the costs. This includes risk stratification, as the probability of a benefit varies depending on the risk of developing breast cancer. Ideally, the group of patients who are screened should be small and should have a high lifetime risk. To date, only age has been taken into consideration in the large populationbased screening programs in Germany. However, including more risk factors and possibly serum or urine tests that might improve diagnostic accuracy, such as circulating nucleic acids [99] and serum markers, might help increase benefits and reduce the risks and costs of screening.

It can also be assumed that the screening methods used differ between women who are more likely to develop one subtype of breast cancer rather than another subtype. It is known, for example, that lobular cancers have a different appearance from ductal cancers and are difficult to detect [100]. Similarly, basal-like tumors seem to have a different appearance on ultrasound and mammography from that of other breast cancer subtypes [101, 102]. The ability to predict which type of cancer a woman may develop might therefore increase the accuracy of detection procedures and could help individualize early detection of breast cancer.

\section{Prophylactic surgery}

In women who have a clearly increased risk of breast cancer, such as BRCA mutation carriers, prophylactic surgery with immediate reconstruction is an option that can reduce the breast cancer risk by $90-100 \%$ [103-106]. There are as yet no detailed guidelines for the relevant indications and techniques. A significant proportion of breast tissue is left in the area of the areola after subcutaneous mastectomy. Total mastectomy is capable of reducing breast tissues by 90-95\%; only total mastectomy (with immediate reconstruction) provides the maximum degree of prevention [107].

\section{Chemoprevention}

Chemoprevention must be feasible and is required to have few or no side effects. Since healthy women are being treated, the harm/ benefit ratio has to be extremely low. This is obviously the reason why women who are offered treatments with relevant side effects rarely proceed with drug intake after the initial consultation $[108,109]$. Drugs currently under discussion, such as tamoxifen or aromatase inhibitors, have relevant side effects such as musculoskeletal pain and have a substantial impact on quality of life [110].

However, the evidence that antihormonal treatment can reduce breast cancer is quite consistent, particularly for the drugs tamoxifen and raloxifene. More than 35000 patients have been treated in chemoprevention studies with tamoxifen, and more than 17000 women with raloxifene [59]. In a meta-analysis, the risk reduction with tamoxifen was reported to be 0.67 (95\% CI, $0.52-0.86$ ) and with raloxifene 0.41 (95\% CI, 0.27-0.62). Comparison between the two risk reduction values is not feasible, as the raloxifene trials included mainly older and exclusively postmenopausal women [59]. It has recently been reported that exemestane, as the first aromatase inhibitor, was able to reduce the breast cancer risk, with an HR of 0.47 (95\% CI, 0.27-0.79), in postmenopausal women with an increased risk for breast cancer [111]. Studies on anastrozole are still ongoing [112].

\section{Conclusions}

\section{$\nabla$}

Information about risk factors for breast cancer is growing at an accelerating speed, with the formation of large international consortia that are capable of handling risk factor data on hundreds of thousands of breast cancer patients and healthy controls and which are capable of carrying out high-throughout genotyping and molecular analyses, such as the Collaborative Oncological Gene-Environment Study (COGS) consortium (http://cogseu. org/). Applications in clinical practice are not yet clear, although it appears to be possible to distinguish between patients with a very low, low, medium, high, or very high risk of breast cancer. Tailoring of individualized breast cancer prevention measures must be the next step, including risk assessment, cancer detection, and molecular profiling. This should lead to early detection and prevention measures focusing on women who have a high likelihood of developing an aggressive breast cancer and ensuring that the necessary measures are not overlooked in women with a low risk of breast cancer.

\section{Conflict of Interest}

\section{$\nabla$}

The authors declare that they have no conflict of interest.

\section{Affiliations}

${ }^{1}$ Universitäts-Brustzentrum Franken, Frauenklinik des Universitätsklinikums Erlangen, Friedrich-Alexander Universität Erlangen-Nürnberg, Comprehensive Cancer Center Erlangen-Nürnberg, Erlangen

${ }^{2}$ Institut für Humangenetik, Friedrich-Alexander Universität Erlangen-Nürnberg, Erlangen

3 Institut für Pathologie, Universitätsklinikum Erlangen, Friedrich-Alexander Universität Erlangen-Nürnberg, Erlangen

${ }^{4}$ Institut für Diagnostische Radiologie, Universitätsklinikum Erlangen, Friedrich-Alexander Universität Erlangen-Nürnberg, Erlangen

\section{References}

1 Fasching PA, Fehm T, Janni W et al. Breast cancer therapy - a state of the art review. Geburtsh Frauenheilk 2010; 70: 875-886

2 Liedtke C, Kiesel L. Basal/triple negative breast cancer. Geburtsh Frauenheilk 2009; 69: 309-315

3 Liedtke C, Wolf MK, Kiesel L. New concepts for targeted systemic therapy in breast cancer. Geburtsh Frauenheilk 2010; 70: 625-633

4 Ruschoff J, Nagelmeier I, Middel P et al. The role of Her-2/neu in the carcinogenesis of breast cancer - when and where? Geburtsh Frauenheilk 2009; 69: 711-716

5 Miki Y, Swensen J, Shattuck-Eidens D et al. A strong candidate for the breast and ovarian cancer susceptibility gene BRCA1. Science 1994; 266: 66-71

6 Wooster R, Bignell G, Lancaster J et al. Identification of the breast cancer susceptibility gene BRCA2. Nature 1995; 378: 789-792

7 Shattuck-Eidens D, Oliphant A, McClure M et al. BRCA1 sequence analysis in women at high risk for susceptibility mutations. Risk factor analysis and implications for genetic testing. JAMA 1997; 278: 1242-1250

8 Couch FJ, Weber BL. Mutations and polymorphisms in the familial early-onset breast cancer (BRCA1) gene. Breast Cancer Information Core. Hum Mutat 1996; 8: 8-18

9 Antoniou A, Pharoah PD, Narod S et al. Average risks of breast and ovarian cancer associated with BRCA1 or BRCA2 mutations detected in case Series unselected for family history: a combined analysis of 22 studies. Am J Hum Genet 2003; 72: 1117-1130

10 Szabo CI, King MC. Population genetics of BRCA1 and BRCA2. Am J Hum Genet 1997; 60: 1013-1020

11 Carlson CS, Eberle MA, Kruglyak L et al. Mapping complex disease loci in whole-genome association studies. Nature 2004; 429: 446-452

12 Cargill M, Altshuler D, Ireland J et al. Characterization of single-nucleotide polymorphisms in coding regions of human genes. Nat Genet 1999; 22: 231-238

13 Thorisson GA, Smith AV, Krishnan $L$ et al. The International HapMap Project web site. Genome Res 2005; 15: 1592-1593 
14 The International HapMap Project. The International HapMap Project. Nature 2003; 426: 789-796

15 Sachidanandam R, Weissman D, Schmidt SC et al. A map of human genome sequence variation containing 1.42 million single nucleotide polymorphisms. Nature 2001; 409: 928-933

16 Risch N, Merikangas $K$. The future of genetic studies of complex human diseases. Science 1996; 273: 1516-1517

17 National Institutes of Health. Policy for sharing of data obtained in $\mathrm{NIH}$ supported or conducted genome-wide association studies (GWAS). Federal Regist 2007; 72: 49290-49297

18 Easton DF, Pooley KA, Dunning AM et al. Genome-wide association study identifies novel breast cancer susceptibility loci. Nature 2007; 447: 1087-1093

19 Ahmed S, Thomas G, Ghoussaini M et al. Newly discovered breast cancer susceptibility loci on 3p24 and 17q23.2. Nat Genet 2009; 41: 585-590

20 Stacey SN, Manolescu A, Sulem P et al. Common variants on chromosome $5 \mathrm{p} 12$ confer susceptibility to estrogen receptor-positive breast cancer. Nat Genet 2008; 40: 703-706

21 Milne RL, Benitez J, Nevanlinna $H$ et al. Risk of estrogen receptor-positive and -negative breast cancer and single-nucleotide polymorphism 2q35-rs13387042. J Natl Cancer Inst 2009; 101: 1012-1018

22 Milne RL, Goode EL, Garcia-Closas M et al. Confirmation of $5 \mathrm{p} 12$ as a susceptibility locus for progesterone-receptor-positive, lower grade breast cancer. Cancer Epidemiol Biomarkers Prev 2011; 20: 2222-2231

23 Breast Cancer Association Consortium. Commonly studied single-nucleotide polymorphisms and breast cancer: results from the Breast Cancer Association Consortium. J Natl Cancer Inst 2006; 98: 13821396

24 Cox A, Dunning AM, Garcia-Closas $M$ et al. A common coding variant in CASP8 is associated with breast cancer risk. Nat Genet 2007; 39: 352358

25 Collaborative Group on Hormonal Factors in Breast Cancer. Breast cancer and breastfeeding: collaborative reanalysis of individual data from 47 epidemiological studies in 30 countries, including 50302 women with breast cancer and 96973 women without the disease. Lancet 2002; 360: 187-195

26 Lambe M, Hsieh C, Trichopoulos D et al. Transient increase in the risk of breast cancer after giving birth. N Engl J Med 1994; 331: 5-9

27 Manson JE, Hsia J, Johnson KC et al. Estrogen plus progestin and the risk of coronary heart disease. N Engl J Med 2003; 349: 523-534

28 Chlebowski RT, Hendrix SL, Langer RD et al. Influence of estrogen plus progestin on breast cancer and mammography in healthy postmenopausal women: the Women's Health Initiative Randomized Trial. JAMA 2003; 289: 3243-3253

29 Million Women Study Collaborators. Breast cancer and hormone-replacement therapy in the Million Women Study. Lancet 2003; 362: 419-427

30 Albring C, Baum E, Beckermann MJ et al. Hormone therapy in the peri and postmenopausal women - short version of the S3-guideline. Geburtsh Frauenheilk 2010; 70: R64-R76

31 Ravdin PM, Cronin KA, Howlader $N$ et al. The decrease in breast-cancer incidence in 2003 in the United States. N Engl J Med 2007; 356: 16701674

32 Katalinic A, Rawal R. Decline in breast cancer incidence after decrease in utilisation of hormone replacement therapy. Breast Cancer Res Treat 2008; 107: 427-430

33 Chlebowski RT, Anderson GL, Gass $M$ et al. Estrogen plus progestin and breast cancer incidence and mortality in postmenopausal women. JAMA 2010; 304: 1684-1692

34 Kenemans P, Kubista E, Foidart JM et al. Safety of tibolone in the treatment of vasomotor symptoms in breast cancer patients - design and baseline data 'LIBERATE' trial. Breast 2007; 16 (Suppl. 2): S182-S189

35 Kenemans P, Bundred NJ, Foidart JM et al. Safety and efficacy of tibolone in breast-cancer patients with vasomotor symptoms: a double-blind, randomised, non-inferiority trial. Lancet Oncol 2009; 10: 135-146

36 Untch M, Beckmann MW, Emons G et al. The LIBERATE study: hormone replacement therapy with tibolone increases the risk of recurrence and metastases in breast cancer patients. Geburtsh Frauenheilk 2009; 69: 199-201

37 McCormack VA, dos Santos Silva I. Breast density and parenchymal patterns as markers of breast cancer risk: a meta-analysis. Cancer Epidemiol Biomarkers Prev 2006; 15: 1159-1169

38 Heusinger $K$, Loehberg $C R$, Haeberle L et al. Mammographic density as a risk factor for breast cancer in a German case-control study. Eur J Cancer Prev 2011; 20: 1-8
39 Boyd NF, Guo H, Martin LJ et al. Mammographic density and the risk and detection of breast cancer. N Engl J Med 2007; 356: 227-236

40 Wolfe JN, Saftlas AF, Salane M. Mammographic parenchymal patterns and quantitative evaluation of mammographic densities: a case-control study. AJR Am J Roentgenol 1987; 148: 1087-1092

41 Wolfe JN. Breast patterns as an index of risk for developing breast cancer. AJR Am J Roentgenol 1976; 126: 1130-1137

42 Boyd NF, Byng JW, Jong RA et al. Quantitative classification of mammographic densities and breast cancer risk: results from the Canadian National Breast Screening Study. J Natl Cancer Inst 1995; 87: 670-675

43 Gao J, Warren R, Warren-Forward H et al. Reproducibility of visual assessment on mammographic density. Breast Cancer Res Treat 2008; 108: $121-127$

44 Boyd NF, Martin LJ, Yaffe M et al. Mammographic density. Breast Cancer Res 2009; 11 (Suppl. 3): S4

45 Byng JW, Boyd NF, Fishell E et al. The quantitative analysis of mammographic densities. Phys Med Biol 1994; 39: 1629-1638

46 Ursin G, Astrahan MA, Salane $M$ et al. The detection of changes in mammographic densities. Cancer Epidemiol Biomarkers Prev 1998; 7: 43 47

47 Vachon CM, Kuni CC, Anderson $\mathrm{K}$ et al. Association of mammographically defined percent breast density with epidemiologic risk factors for breast cancer (United States). Cancer Causes Control 2000; 11: 653-662

48 Butler LM, Gold EB, Greendale GA et al. Menstrual and reproductive factors in relation to mammographic density: the Study of Women's Health Across the Nation (SWAN). Breast Cancer Res Treat 2008; 112: $165-174$

49 Loehberg CR, Heusinger K, Jud SM et al. Assessment of mammographic density before and after first full-term pregnancy. Eur J Cancer Prev 2010; 19: 405-412

50 Boyd NF, Martin LJ, Bronskill M et al. Breast tissue composition and susceptibility to breast cancer. J Natl Cancer Inst 2010; 102: 1224-1237

51 World Cancer Fund, Hrsg. Krebsprävention durch Ernährung. Forschung, Daten, Begründungen, Empfehlungen. Potsdam-Rehbrücke: Deutsches Institut für Ernährungsforschung (DIfE); 2003: 1-28

52 Bundesforschungsinstitut für Ernährung und Lebensmittel, Hrsg. Nationale Verzehrsstudie II, Teil 1. Karlsruhe: Max Rübner Institut; 2008: $1-143$

53 Berrington de Gonzalez A, Sweetland S, Spencer E. A meta-analysis of obesity and the risk of pancreatic cancer. Br J Cancer 2003; 89: 519523

54 Benson VS, Pirie K, Green J et al. Lifestyle factors and primary glioma and meningioma tumours in the Million Women Study cohort. $\mathrm{Br}$ J Cancer 2008; 99: 185-190

55 Vainio H, Kaaks R, Bianchini F. Weight control and physical activity in cancer prevention: international evaluation of the evidence. Eur J Cancer Prev 2002; 11 (Suppl. 2): S94-S100

56 Bianchini $F$, Kaaks $R$, Vainio $H$. Weight control and physical activity in cancer prevention. Obes Rev 2002; 3: 5-8

57 Harvie M, Howell A, Vierkant RA et al. Association of gain and loss of weight before and after menopause with risk of postmenopausal breast cancer in the Iowa women's health study. Cancer Epidemiol Biomarkers Prev 2005; 14: 656-661

58 Brennan SF, Cantwell MM, Cardwell CR et al. Dietary patterns and breast cancer risk: a systematic review and meta-analysis. Am J Clin Nutr 2010; 91: 1294-1302

59 Cummings SR, Tice JA, Bauer S et al. Prevention of breast cancer in postmenopausal women: approaches to estimating and reducing risk. J Natl Cancer Inst 2009; 101: 384-398

60 Michels KB, Mohllajee AP, Roset-Bahmanyar E et al. Diet and breast cancer: a review of the prospective observational studies. Cancer 2007; 109: 2712-2749

61 Yin L, Grandi N, Raum E et al. Meta-analysis: serum vitamin D and breast cancer risk. Eur J Cancer 2010; 46: 2196-2205

62 Van 't Veer P, van Leer EM, Rietdijk A et al. Combination of dietary factors in relation to breast-cancer occurrence. Int J Cancer 1991; 47: 649-653

63 Landa MC, Frago N, Tres A. Diet and the risk of breast cancer in Spain. Eur J Cancer Prev 1994; 3: 313-320

64 Zaridze D, Lifanova Y, Maximovitch D et al. Diet, alcohol consumption and reproductive factors in a case-control study of breast cancer in Moscow. Int J Cancer 1991; 48: 493-501

65 Negri E, La Vecchia C, Franceschi $S$ et al. Intake of selected micronutrients and the risk of breast cancer. Int J Cancer 1996; 65: 140-144 
66 Adzersen KH, Jess P, Freivogel KW et al. Raw and cooked vegetables, fruits, selected micronutrients, and breast cancer risk: a case-control study in Germany. Nutr Cancer 2003; 46: 131-137

67 Boyapati SM, Shu XO, Jin F et al. Dietary calcium intake and breast cancer risk among Chinese women in Shanghai. Nutr Cancer 2003; 46: 38 43

68 Levi F, Pasche C, Lucchini F et al. Dietary intake of selected micronutrients and breast-cancer risk. Int J Cancer 2001; 91: 260-263

69 Katsouyanni K, Willett W, Trichopoulos D et al. Risk of breast cancer among Greek women in relation to nutrient intake. Cancer 1988; 61: 181-185

70 Trock BJ, Hilakivi-Clarke L, Clarke R. Meta-analysis of soy intake and breast cancer risk. J Natl Cancer Inst 2006; 98: 459-471

$71 \mathrm{Wu} A H, \mathrm{Yu}$ MC, Tseng CC et al. Epidemiology of soy exposures and breast cancer risk. Br J Cancer 2008; 98: 9-14

72 Milne RL, Gaudet MM, Spurdle AB et al. Assessing interactions between the associations of common genetic susceptibility variants, reproductive history and body mass index with breast cancer risk in the breast cancer association consortium: a combined case-control study. Breast Cancer Res 2010; 12: R110

73 Travis RC, Reeves GK, Green J et al. Gene-environment interactions in 7610 women with breast cancer: prospective evidence from the Million Women Study. Lancet 2010; 375: 2143-2151

74 Campa D, Kaaks R, Le Marchand $L$ et al. Interactions between genetic variants and breast cancer risk factors in the breast and prostate cancer cohort consortium. J Natl Cancer Inst 2011; 103: 1252-1263

75 Prentice RL. Empirical evaluation of gene and environment interactions: methods and potential. J Natl Cancer Inst 2011; 103: 1209-1210

76 Berry DA, Iversen jr. ES, Gudbjartsson DF et al. BRCAPRO validation, sensitivity of genetic testing of BRCA1/BRCA2, and prevalence of other breast cancer susceptibility genes. J Clin Oncol 2002; 20: 2701-2712

77 Parmigiani G, Berry D, Aguilar O. Determining carrier probabilities for breast cancer-susceptibility genes BRCA1 and BRCA2. Am J Hum Genet 1998; 62: 145-158

78 Parmigiani G. BRCAPRO. Internet: http://astor.som.jhmi.edu/ BayesMendel/brcapro.html; Stand: 1.11.2011

79 Antoniou AC, Cunningham AP, Peto J et al. The BOADICEA model of genetic susceptibility to breast and ovarian cancers: updates and extensions. Br J Cancer 2008; 98: 1457-1466

80 Antoniou AC, Pharoah PP, Smith P et al. The BOADICEA model of genetic susceptibility to breast and ovarian cancer. Br J Cancer 2004; 91: 1580 1590

81 Tyrer J, Duffy SW, Cuzick J. A breast cancer prediction model incorporating familial and personal risk factors. Stat Med 2004; 23: 1111-1130

82 Antoniou A. BOADICEA. Internet: http://www.srl.cam.ac.uk/genepi/ boadicea/boadicea_home.html; Stand: 1.11.2011

83 National Institutes of Health. Breast cancer risk assessment tool. Internet: http://www.cancer.gov/bcrisktool/; Stand: 1.11.2011

84 Gail MH, Benichou J. Validation studies on a model for breast cancer risk. J Natl Cancer Inst 1994; 86: 573-575

85 Claus EB, Risch N, Thompson WD. The calculation of breast cancer risk for women with a first degree family history of ovarian cancer. Breast Cancer Res Treat 1993; 28: 115-120

86 Tice JA, Cummings SR, Smith-Bindman R et al. Using clinical factors and mammographic breast density to estimate breast cancer risk: development and validation of a new predictive model. Ann Intern Med 2008; 148: $337-347$

87 Milne RL, Antoniou AC. Genetic modifiers of cancer risk for BRCA1 and BRCA2 mutation carriers. Ann Oncol 2011; 22 (Suppl. 1): i11-i17

88 Wacholder S, Hartge P, Prentice R et al. Performance of common genetic variants in breast-cancer risk models. N Engl J Med 2010; 362: 986993

89 Azzato EM, Tyrer J, Fasching PA et al. Association between a germline OCA2 polymorphism at chromosome 15q13.1 and estrogen receptornegative breast cancer survival. J Natl Cancer Inst 2010; 102: 650-662

90 Antoniou AC, Wang X, Fredericksen ZS et al. A locus on 19p13 modifies risk of breast cancer in BRCA1 mutation carriers and is associated with hormone receptor-negative breast cancer in the general population. Nat Genet 2010; 42: 885-892

91 Yang XR, Chang-Claude J, Goode EL et al. Associations of breast cancer risk factors with tumor subtypes: a pooled analysis from the Breast Cancer Association Consortium studies. J Natl Cancer Inst 2011; 103: 250-263
92 Broeks A, Schmidt MK, Sherman ME et al. Low penetrance breast cancer susceptibility loci are associated with specific breast tumor subtypes: findings from the Breast Cancer Association Consortium Hum Mol Genet 2011; 20: 3289-3303

93 Stevens KN, Vachon CM, Lee AM et al. Common breast cancer susceptibility loci are associated with triple-negative breast cancer. Cancer Res 2011; 71: 6240-6249

94 Kaufmann M, Rody A. Breast cancer: reduced mortality by early detection and adjuvant therapy. Geburtsh Frauenheilk 2009; 69: 218-232

95 Katalinic A. Breast cancer: declining mortality despite its increasing incidence. Geburtsh Frauenheilk 2009; 69: 237-239

96 Wunderlich P, Plodeck V, Kast Ket al. Intensified screening program for women with hereditary predisposition to develop breast cancer - our study results and current knowledge in the literature. Geburtsh Frauenheilk 2009; 69: 623-630

97 Kast K, Distler W, Schmutzler R. Current recommendations for the prevention and treatment of hereditary breast cancer. Geburtsh Frauenheilk 2010; 70: 634-639

98 Pfandzelter $R$, Wulfing $U$, Boedeker B et al. Diagnostic image quality of mammograms in German outpatient medical care. Geburtsh Frauenheilk 2010; 70: 998-1005

99 Lange J, Leidinger P, Oehler T et al. miRNA biomarkers from blood - a promising approach for minimally invasive diagnostic testing. Geburtsh Frauenheilk 2010; 70: 137-141

100 Hauth EA, Wostmann A, Heindel W. Diagnostic imaging of invasive lobular breast carcinoma. Geburtsh Frauenheilk 2009; 69: 836-841

101 Kojima Y, Tsunoda H. Mammography and ultrasound features of triple-negative breast cancer. Breast Cancer 2011; 18: 146-151

102 Choi YJ, Seong MH, Choi SH et al. Ultrasound and clinicopathological characteristics of triple receptor-negative breast cancers. J Breast Cancer 2011; 14: 119-123

103 Meijers-Heijboer H, van Geel B, van Putten WL et al. Breast cancer after prophylactic bilateral mastectomy in women with a BRCA1 or BRCA2 mutation. N Engl J Med 2001; 345: 159-164

104 Meijers-Heijboer H, Brekelmans CT, Menke-Pluymers $M$ et al. Use of genetic testing and prophylactic mastectomy and oophorectomy in women with breast or ovarian cancer from families with a BRCA1 or BRCA2 mutation. J Clin Oncol 2003; 21: 1675-1681

105 Hartmann LC, Sellers TA, Schaid DJ et al. Efficacy of bilateral prophylactic mastectomy in BRCA1 and BRCA2 gene mutation carriers. J Nat Cancer Inst 2001; 93: 1633-1637

106 Hartmann LC, Schaid DJ, Woods JE et al. Efficacy of bilateral prophylactic mastectomy in women with a family history of breast cancer. $\mathrm{N}$ Engl J Med 1999; 340: 77-84

107 Hughes KS, Papa MZ, Whitney T et al. Prophylactic mastectomy and inherited predisposition to breast carcinoma. Cancer 1999; 86: 2502 2516

108 Fasching PA, von Minckwitz G, Fischer T et al. The impact of breast cancer awareness and socioeconomic status on willingness to receive breast cancer prevention drugs. Breast Cancer Res Treat 2007; 101: 95-104

109 Loehberg CR, Jud SM, Haeberle L et al. Breast cancer risk assessment in a mammography screening program and participation in the IBIS-Il chemoprevention trial. Breast Cancer Res Treat 2010; 121: 101-110

110 Distler W, Canzler U, Duffy SR et al. Undesirable gynaecological and operative interventions during treatment of breast cancer with anastrozole and tamoxifen. Geburtsh Frauenheilk 2010; 70: 57-61

111 Goss PE, Ingle JN, Ales-Martinez JE et al. Exemestane for breast-cancer prevention in postmenopausal women. N Engl J Med 2011; 364 : 2381-2391

112 Cuzick J. IBIS II: a breast cancer prevention trial in postmenopausal women using the aromatase inhibitor anastrozole. Expert Rev Anticancer Ther 2008; 8: 1377-1385

113 Antoniou AC, Sinilnikova OM, Simard J et al. RAD51 135G->C modifies breast cancer risk among BRCA2 mutation carriers: results from a combined analysis of 19 studies. Am J Hum Genet 2007; 81: 11861200

114 Engel C, Versmold B, Wappenschmidt B et al. Association of the variants CASP8 D302H and CASP10 V410I with breast and ovarian cancer risk in BRCA1 and BRCA2 mutation carriers. Cancer Epidemiol Biomarkers Prev 2010; 19: 2859-2868

115 Antoniou AC, Spurdle AB, Sinilnikova OM et al. Common breast cancerpredisposition alleles are associated with breast cancer risk in BRCA1 and BRCA2 mutation carriers. Am J Hum Genet 2008; 82: 937-948 
116 Antoniou AC, Sinilnikova OM, McGuffog $L$ et al. Common variants in LSP1, 2q35 and 8q24 and breast cancer risk for BRCA1 and BRCA2 mutation carriers. Hum Mol Genet 2009; 18: 4442-4456

117 Antoniou AC, Kartsonaki C, Sinilnikova OM et al. Common alleles at 6q25.1 and 1p11.2 are associated with breast cancer risk for BRCA1 and BRCA2 mutation carriers. Hum Mol Genet 2011; 20: 3304-3321

118 Spiegelman D, Colditz GA, Hunter D et al. Validation of the Gail et al. model for predicting individual breast cancer risk. J Natl Cancer Inst 1994; 86: 600-607

119 Dupont WD, Page DL. Risk factors for breast cancer in women with proliferative breast disease. N Engl J Med 1985; 312: 146-151

120 Pike MC, Siiteri PK, Welsch CW et al. The Epidemiology of Breast Cancer as it relates to Menarche, Pregnancy, and Menopause. Cold Spring Harbor: Cold Spring Harbor Laboratory; 1981: 3-21

121 Brinton LA, Schairer C, Hoover RN et al. Menstrual factors and risk of breast cancer. Cancer Invest 1988; 6: 245-254

122 Kelsey JL, Gammon MD, John EM. Reproductive factors and breast cancer. Epidemiol Rev 1993; 15: 36-47

123 Saftlas AF, Hoover RN, Brinton LA et al. Mammographic densities and risk of breast cancer. Cancer 1991; 67: 2833-2838

124 Byrne C, Schairer C, Wolfe J et al. Mammographic features and breast cancer risk: effects with time, age, and menopause status. J Natl Cancer Inst 1995; 87: 1622-1629
125 van Gils CH, Hendriks JH, Otten JD et al. Parity and mammographic breast density in relation to breast cancer risk: indication of interaction. Eur J Cancer Prev 2000; 9: 105-111

126 Thomas DB, Carter RA, Bush jr. WH et al. Risk of subsequent breast cancer in relation to characteristics of screening mammograms from women less than 50 years of age. Cancer Epidemiol Biomarkers Prev 2002; 11: 565-571

127 Torres-Mejia G, De Stavola B, Allen DS et al. Mammographic features and subsequent risk of breast cancer: a comparison of qualitative and quantitative evaluations in the Guernsey prospective studies. Cancer Epidemiol Biomarkers Prev 2005; 14: 1052-1059

128 Nagata C, Matsubara T, Fujita $H$ et al. Mammographic density and the risk of breast cancer in Japanese women. Br J Cancer 2005; 92: 21022106

129 Maskarinec G, Pagano I, Lurie G et al. A longitudinal investigation of mammographic density: the multiethnic cohort. Cancer Epidemiol Biomarkers Prev 2006; 15: 732-739

130 Kotsuma Y, Tamaki Y, Nishimura T et al. Quantitative assessment of mammographic density and breast cancer risk for Japanese women. Breast 2008; 17: 27-35

131 Wong CS, Lim GH, Gao F et al. Mammographic density and its interaction with other breast cancer risk factors in an Asian population. Br J Cancer 2011; 104: 871-874 